\title{
The Analysis of Micro Business Empowerment Policy Implementation in Makassar City, Indonesia
}

\author{
Muhammad Guntur ${ }^{1}$, Henni Zainal ${ }^{2}$ and Aslinda ${ }^{3}$ \\ ${ }^{1}$ Universitas Negeri Makassar, Indonesia, e-mail: m.guntur@unm.ac.id \\ ${ }^{2}$ Universitas Indonesia Timur, Indonesia, e-mail: henni zainal@yahoo.com \\ ${ }^{3}$ Universitas Negeri Makassar, Indonesia
}

\begin{abstract}
One of the ways that the job seekers find their livelihood in big cities is by trading in the informal sector that is termed with a street vendor. Street vendors are trading by holding their merchandise with benches/tables, mats, and other supporting tools. The presence of street vendors in the city of Makassar is often found to cause many problems related to disturbances of the public order and security. The shabby impression, wild, and reducing the beauty of the city, seems to be an image that attached to this micro business where the street vendors often trading on the sidewalks, city parks and sometimes on the road. The purpose of this study is to know the implementation of micro business empowerment policy in Makassar City. This research was conducted in Makassar City by using a qualitative approach with a purposive technique according to the needs of the study. The result of this study found that the analysis of the implementation of the policy using the Edwards III model has not been able to solve the problems that occur.
\end{abstract}

Keywords: Policy Implementation, Empowerment, Microbusiness actors.

\section{Introduction}

Cities with all its attractiveness in terms of progress compared to villages, make rural communities urbanize. The rapid growth of the population in an urban area in Indonesia is mainly caused by the urbanization and the expansion of the city itself. This situation causes employment needs in urban areas much higher. Along with this, it turns out that the formal sector is unable to absorb all the additional labors who came to the city. As a result, an excess of labor is not accommodated, flows, and then finally accelerates the growth of the informal sector.

One of the cities that attract job seekers in various sectors is Makassar City. It is the fourth largest city in Indonesia and the largest in Eastern Indonesia. It has an area of about $175.79 \mathrm{~km}^{2}$ with a population of around 1.4 million. Thus; the City of Makassar can be said as a metropolitan city. The increasing number of people in Makassar City from year to year is caused by the increasing number of people who come to this city from the outside of Makassar City to try their luck and continue their education in Makassar City.

The presence of street vendors along the road of Makassar City should be seriously concerned by the government because it is the cause of congestion in many areas of roads. So far, the problem of street vendors management is always ended with conflict because the government has not been able to anticipate it and seems to be ignore and with the presence of street vendors. On the other hand, it cannot be blamed entirely to the street vendors, who trade there because they must do that to feed their entire family. The presence of street vendors in the city of Makassar, if it is well-organized and well-managed, its existence will make the tourist locations in the middle of the city become more beautiful. This can be realized not only from the efforts of the government of the city but also from the active participation of the elements of society. The government of the city, in this case, is the relevant agency, that should be able to play an active role in formulating, fostering and managing the street vendors. Various policies have been made by the government of the city to overcome the problem of the street vendors, but sometimes the implementation is not as desired or what is wanted by everyone. 
From the phenomena that have been observed, to think more deeply about how to solve the problem of street vendors are certainly becomes the duty of all components of society and this is inseparable from the role of the Civil Service Police (SATPOL PP). From this phenomenon, the researchers wanted to explore further about how far the implementation of Regional Regulation No. 10 of 1990 concerning the development of the street vendors along with the factors that support and hinder the implementation of the Regional Regulation, while reviewing various efforts made by the Government of Makassar City in conducting micro business empowerment activities.

Wahab (2005) which is also following the idea of Mazmanian and Sabatier that the process of the implementation of the policy is actually not only concerned with the behavior of administrative agency which responsible for implementing the program and causing self-sufficiency in the target group, but also concerning networks of political, economic, social, power which can directly or indirectly affect the behavior of all parties involved, which in turn to give a significant impacts, whether it expected or unexpected impact. (Leo. Agustino, 2006) provides an understanding of policy implementation as follows: "Policy implementation is an effort to achieve certain goals with certain means of a certain time sequence using the chosen facilities to achieve the chosen goal".

A Framework for Implementation Analysis developed by Daniel Mazmanian and Paul A. Sabatier (1983). Mazmanian and Sabatier as cited by (Leo Agustino, 2006), classify the policy implementation process into three variables. First, the independent variables, namely the ease of the problem is controlled which is related to the indicators of the problem of the theory and technical implementers, the diversity of objects, and what changes are wanted. Second, intervening variables, namely the variable of the ability of the policy to structure the implementation process with indicators of clarity and consistency of objectives, the use of causal theory, accuracy of allocation of funding sources, hierarchical integration between the implementing institutions, implementing rules, and openness to all of outside parties; and non-policy variables that affect the implementation process with regard to the indicators of socio-economic and technological conditions, public support, attitudes and resources from constituents, support from higher officials, and the commitment and leadership quality of the officials who implement the policy. Third, the dependent variable, namely the stages in the implementation process with five stages, including the understanding of the implementing agency/institution in terms of implementing policies, object compliance, the results, acceptance of the results, and finally the leading to revisions of policies made and implemented or overall fundamental policy.

The model of public policy implementation offered by Daniel Mazmanian and Paul Sabatier is called A Framework for Policy Implementation Analysis. Both experts said that the important role of the implementation of public policy is their ability to identify variables that influence the achievement of formal objectives throughout the implementation process.

Selection of the Policy Implementation Model. In this study researchers use a to George Edwards III cited by (Nugroho, 2006) In reviewing the policy implementation, Edwards discussed four determinant factors or variables in the implementation of public policy. Those main factors or variables are:

a. Communication

b. Sources

c. Tendency or behavior

d. Bureaucratic structure

With the four factors mentioned above, the researcher analyzes the implementation of policies related to the empowerment of the street vendors comprehensively.

The Empowerment of the Street Vendors (Sumaryadi, 2005) gives two meanings of empowerment, namely: (a) to give power or authority to is giving power, diverting strength or delegating authority to other parties, (b) to give access to or to enable is to provide the empowerment. This view states that empowering means dividing power from powerful people or groups to those who do not have it (powerless) so that there is a balance between the authorities and those who are empowered, so that 
deceptive conditions do not occur. The idea of empowerment will not be separated from the concept of "power" itself. It simply means that the concept of power here does not merely lead to power, but also to the strength, ability or potential that comes more from within an empowered person or group. In empowering the parties that will be empowered, it is very important to involve them in the process of empowerment, so that the goals of empowerment can be achieved optimally. The programs that include the community, have several objectives, that the aid is effective because it is in accordance with the will and recognize their abilities and needs, and increase empowerment of empowered parties with experience in designing, implementing and responsible for self-improvement and economic efforts (Kartasasmita Ginanjar, 1996).(Mulyanto, 2007), street vendors are a large group of workers in the informal sector". The work of street vendors is the last answer facing the process of urbanization, which is coupled with small village-to-large city migration, rapid population growth, slow growth of employment opportunities in the industrial sector, and absorption of morally-denied technology and excessive labor.

In some places, street vendors were disputed for disturbing the motorists. In addition, street vendors use nearby rivers and waterways to dispose of garbage and laundry water. The garbage and soapy water can further damage the rivers by killing the animals which live in the water, like fish and causing eutrophication. However, the street vendors often provide food or other goods at low prices, often, cheaper than buying at a store. The money and costs needed are little or small, so this often invites traders with small capital to start the business or people who are categorized as the people with weak economic power who usually set up businesses around their homes. This family business also constantly strives to improve the performance of its management-based human resource competencies, both those obtained through training and market information sharing, as well as through sharing experiences, (Henni Zainal, Parinsi, Indonesia, Hasan, \& Makassar, 2018).

\section{Research Methodology}

This study employs descriptive research with a qualitative approach that emphasizes the disclosure of meanings and processes related to the behavior and social actions of local communities and the government. Qualitative research is carried out in natural and inventive conditions. The details of the informants/subject in this study are Head of Field and Members of the Civil Service Police and the street vendors who are scattered in several locations in Makassar City. Data collection in this study, namely: the study of literature (Library Research), a field study of the objects (Field Research), namely direct observation of the object under the study. Documentation review, namely the technique used to obtain data through the study of library resources, documents, regulations, laws and decisions, and literature. The analysis of qualitative data will be pursued through: Data reduction (choosing the main things relevant to the research), data display (allowing presentation of data through matrix and graphics according to research needs), data verification and conclusions (looking for the main equations that have appeared in the results of interviews) and collected based on the final analysis of data, data analysis will obtain the credibility, dependability, and confirmation of all the informants.

\section{Result and Discussion}

The policy that issued by the government of Makassar City to regulate the existence of street vendors is an attempt to restore the function of the area belonging to the road in accordance with its designation. The effort is through structuring the business location activities for street vendors. This has implications for the expulsion of street vendors in urban areas whose allocation for public roads that are forbidden to be occupied by traders. With this way which is expected to create clean, orderly, comfortable and safe area, and to keep the beauty of the city and main training the smooth flow of traffic. Of course, the expulsion of the street vendor activities that are in accordance with the laws and regulations aims to prevent and minimize the negative impact of its existence. The arrangement of business locations for street vendors needs to be carried out so that the existence of street vendors who run their business activities will not cause a disturbance to many people. 
Therefore, in every sidewalk of Makassar City, it is not allowed to be occupied by street vendors because its function is only for the pedestrian. The street vendors who are allowed to trade at a place that determined by the Head of the Region in accordance with Article 2 paragraph 1 must have permission or license from him and take responsibility for the cleanliness, order, and security of the place and also prohibited from establishing permanent building or stores. This is according to article 3 of the Local Government Regulation on the Construction of Street Vendors in Makassar City, namely:

"(1) Every street vendor who uses the place of trade/business referred to in article 2 paragraph (1), must have a license or permission from the Head of Region.

(2) Every street vendor as stated in paragraph (1) of this article is responsible for the clean lines, healthy, beauty, security/order and tidiness around the place;

(3) Permanent buildings may not be established or built at places of trade/business that have been granted a license or permission."

The policy was strengthened by the statement of the Head of the Section of Investigation and Enforcement of the Civil Service Police of Makassar City, he said that: "Basically the street vendor is not allowed to trade in the areas that belong to the road, occupying the road because it can disturb the road users. The policy is set in the Regional Regulation Number 10 of 1990, and now there is a Mayor's Regulation that regulates places that are prohibited by street vendors in Makassar City, namely the Mayor's Regulation about the place which can and cannot be used by street vendors and Mayor's Regulations on rectangular pilot areas that must be free from street vendors, the regulation that becomes a reference for us to curb street vendors, those who do not have permit or license and trading in the roadside areas especially in places where roads are prohibited in accordance with the Mayor's Regulations must be dissolve".(Regional regulation number 10 the year of 1990 about the development of the street vendors in Makassar City).

The explanation above reinforces the existence of the Regional Regulations and Mayor's Regulations which become a reference for the Civil Service Police of Makassar City in guiding the street vendors. In addition, the regulations that regulates the places that are prohibited for the street vendors to trade are also regulated by the Mayor of Makassar Decree Number 44 of 2002 concerning the Appointment of Several Court Sites that Can and Can Not Be Used by Street Vendors in Makassar City and the Mayor's Regulation Number 651 of 2007 concerning the Road Quadrangle Area as a Cleanliness Pilot.

This study found that the basis for controlling the street vendors by the Civil Service Police (SATPOL PP)of Makassar City who had the task of enforcing the regulation in Makassar City namely the Regional Regulation No. 10 concerning the Development of Street Vendors concerning the prohibition of trading over the road and without permission. As for the more specific names of roads/places stipulated in the Mayor's Regulation / Decree Number 44 of 2002 and the Mayor's Regulation Number 651 concerning Road Quadrangle Areas.

Judicial prosecution of street vendors who violate the rules is a form of consequence on street vendors who still broke the regulations and will legally processed or executed and then given sanctions or punishment based on the applicable laws and regulations. The forms of street vendor violations such as occupying the area belonging to the road or do not have any permission or license from the Mayor or the local officials of District in accordance with Regional Regulation No. 10 of 1990, and occupying the courtyard or roads which were prohibited by the Government of Makassar City which must be free from street vendors as listed in Mayor's Decree Number 44 of 2002 and the Mayor's Regulation Number 651 of 2007.

The street vendors who are reluctant to be disciplined said that they do not want to be dissolved because of economic factors. If the goods are taken, of course, the street vendors cannot do the trading activity and will finally earn no income. Whereas, working as street vendors is their daily job, where they can fulfill their family's daily needs. 
Street vendors who violate the rules are then be punished with the sanction. They must pay the fine of IDR. 50.000,-and the goods will be returned to the street vendors, approved by the Head of the Section of Investigation and Enforcement in the Law Enforcement Sector of the Civil Service Police of Makassar City. This solution, of course, does not give any deterrent effect to the street vendors who violated the rules, because the punishment or the fines or sanctions is too low. This can be is seen from the several street vendors who repeated their actions to break the rules again after being sanctioned.

The Analysis of the Implementation of the Regional Regulation No. 10 of 1990 concerning the Development of the Street Vendors in Makassar City Using the George Edwards III Model of Policy Implementation.

a. Communication

From the result of the research above, it can be concluded that the implementation of Regional Regulation No. 10 of 1990 concerning the Development of the street vendors in Makassar City did not effective because the flow of communication did not work well between the sectors/agencies that handled the street vendors and they are seems was not well coordinated. That was due to the unclear flow of coordination and communication between the Agency and the district / sub-district and among districts that over shadowed the problem of the street vendors so that the solution of the problems of street vendors did not work well.

The less communication and coordination between the Civil service Police and the Department of Industry and Commerce and between the district sleds to the problem of street vendors seems to be neglected. Furthermore, the treatment of street vendors only covered the aspects of dissolving but not covers the aspect of guiding the street vendors, so that the implementation of the policy eventually meets the resistance from the street vendors in Makassar City.

Therefore, the policy must be able to solve the problems caused by the proliferation and the lack of regulation of the street vendors in Makassar City. As what was conveyed by (Winarno, 2012): "Public policies are basically made to solve problems that exist in society. Therefore, how much contribution given by public policy in solving problems in society becomes an interesting question in evaluating public policy? However, whether the solution to the problem is satisfactory or not, it depends on the accuracy of the public problems mentioned are formulated ".

b. Sources

The implementation of policies must be supported by resources such as human resources, materials, and methods. Even though the goals, objectives, and contents of the policy have been communicated clearly and consistently, but if the implementers are lacking the resources to execute it, the implementation will not run effectively and efficiently. Without resources, the policy is just something that stated on paper or document that is never being realized to provide solutions to problems that exist in the community and to provide benefits to the community. Furthermore (Wahab, 2005) explained that these resources can be human resources, namely the competency of the implementer and financial resources.

Therefore, the implementation of regional regulations can succeed well if it is able to be supported by capable resources in implementing the regulation both the resources relating to the human resources/policy implementers and other supporting resources such as other facilities and infrastructure.

The supervision that is always carried out by the Civil Service Police of Makassar City, of course, requires the availability of adequate facilities and infrastructure such as the need for field officers and patrol vehicles and enough trucks along with other equipment needed to facilitate supervision and control. In return, the availability of funds is needed to support the internal constraints faced by the Civil service Police. The availability of funds is indeed very influential in policy implementation, in accordance with what was stated by Van Metter and Van Horn in (L Agustino, 2008), who stated that "when competent and capable human resources are available while funding through the budget is not 
available, it is indeed a complicated problem to realize what the public policy goals are aiming for ". (L. Agustino, 2008)

c. Tendencies or Behavior

A disposition/tendency in implementation and characteristics, attitudes held by implementor policies, such as strong commitment, honesty, communicative, clever and democratic. The good implementor must have a good disposition, it will be able to implement the policy very well as what is desired and determined by policy makers. If the policy implementation has a different attitude or perspective toward the policy makers, then the implementation process becomes ineffective and inefficient. (Wahab, 2005), explained that disposition is the trait and characteristic possessed by the implementor, such as strong commitment, honesty, democratic. If the implementor has a good disposition, then he will run the policy well as what is desired by policy makers in this case the policy implementor of Regional Regulation No. 10 of 1990 concerning about fostering the street vendors in Makassar City by the Civil Service Police and coordinating with district/ sub-district officials related to arrangement or regulation of street vendors management in Makassar City.

From the result of this study, the implementation of the policy is not running well due to the policies relating to regulation are not suitable with what is expected by the street vendors of Makassar City where there is a prohibition on trading in the area roads or sidewalk, so that the street vendors should be involved in the policy-making process.

Policies and solutions to the problems of street vendors are certainly not expected to be formulated unilaterally by the Government of Makassar City without involving the street vendors. The street vendor policy that can involve all parties/stakeholders in accommodating all interests is certainly the highly expected policy by all parties because a public policy which involving all parties in its production will certainly not to harm the parties that are going to be affected by the policy.

d. Bureaucratic structure

The unclear coordination level and bureaucratic structure that is the responsible for handling street vendors' problems in Makassar City has become the determinant factor of the unsuccessful of the implementation of the Regional Regulations on fostering the street vendors in Makassar City. From the result of the study, it was found that there was no relevant agency that responds to the street vendors' problem so that the development of street vendors in Makassar did not work properly. Moreover, there were only street vendor arrangements without relocation so that the implementation of the policy only led to the eviction of street vendors trading in the street, even though the district and sub-district should be the one who responsible for providing guidance for them such as a proper relocation place for them who trade.

Furthermore, (Wahab, 2005) explained:

"In the implementation of the policy, the organizational structure has an important role. One important aspect of the organizational structure is the existence of Standard Operational Procedures. The function of the standard operating procedures is as the guideline for each implementor in acting. An organizational structure that is too long will tend to weaken the supervision and lead to red-tape, which is a complex and complicated bureaucracy. This may cause inflexible organizational activities in turn.

Therefore, it is necessary to have a clear coordinating bureaucratic structure among the Civil Service Police of Makassar City, the officials of District or Sub-district and the Office of Industry and Commerce in fostering the street vendors in Makassar City. Thus, there will be clarity on the coordination/accountability later for the street vendors in Makassar City. Finally, it is expected that there is clarity about the solution to the existence of the street vendors in Makassar City. As stated by the overall result of the complex mix of persecution, tolerance, regulation, and promotion is usually called "containment." Street vendors are kept out of elite and private areas, and their numbers are limited in the" conflict-zones" of maximum congestion. A few illegal street vending activities are persecuted across the whole city, while support is given to selected vendor types and locations 
considered especially desirable. Meanwhile, the scattered vendors in the poorer and less congested areas of the city are being ignored (Ray Bromley, 2000).

The knowledge of economic advancement through economic cooperation must be taught with words and deeds and delivered at every level and at every opportunity. There is no better place for the instruction to begin than in the streets. Street vending is a microcosm of black entrepreneurship, with all its potential and its problems. Street vending is open, obvious, and economic law breaking, and finally, street vending presents an opportunity where ordinary, everyday people, whether sellers or consumers, can engage in the political contest to build a more viable public sphere and feel directly the result of their work. (Austin et al., 2017).

The fact that street vendors remain on the streets of the historic center indicates that the ability of the program to render them is fundamentally defied. Their presence represents not only a challenge to the exclusionary nature of the program, but it is an indication of social bond and networks that the program sought to rupture, in fact, have been reconstituted. (Crossa, 2009).

\section{Conclusion}

The implementation of the Regional Regulation No. 10 of 1990 concerning the Fostering of the Street Vendors were carried out with socialization and counseling directly to the street vendors and carried out by the Civil Service Police. The implementation of the Regional Regulation was implemented in several stages for street vendors who did not heed the regulation, where the first action was given as a form of warning to street vendors or commonly called non-judicial preventive measures, for the next stage judicial enforcement was implemented as stipulated in the Civil Service Police of Makassar City standard operational procedures.

The analysis of the implementation of the policy using the Edwards III model has not been able to eliminate the existing problems. This is caused by the unclear coordination and bureaucratic structures that are responsible for handling the street vendors' problems in Makassar City so that the flow of communication that runs between sectors/services with those who handle the street vendors are seemed not well-coordinated. In addition, the policies related to street vendors in their formulation did not involve the street vendors.

\section{References}

Agustino, L. 2006. Dasar- dasar Kebijakan Public. Bandung: Alfa beta. Agustino, L. 2008. Dasar- dasar Kebijakan Publik. Bandung. Alfabeta.

Austin, R. The, S, Law Y, S, Economy.I. 2017. Symposium: The Informal Economy, 103 (8), 21192131.

Crossa, V. 2009. Resisting the entrepreneurial city: Street vendors struggle in Mexico City's historic center. International journal of urban and regional research, 33 (1). 43-63. https://doi.org/10.1111/j.1468-2427.2008.00823.x

Henni Zainal, U. I. T., Parinsi, W. K., Indonesia, S. P., Hasan, M., \& Makassar, U. N. (2018). The Influence of Strategic Assets and Market Orientation to The Performance of Family Business In Makassar City , Indonesia, 17(6), 1-9.

Kartasasmita Ginanjar. (1996). Pembangunan untuk Rakyat Memadukan Pertum buhan dan Pemerataan. Jakarta: PT. Pustaka Cidesindo.

Law Number 20 of 2008 concerning Micro, S. and M. E. (n.d.). No Title.

Mulyanto. (2007). Pengembangan dan Pengukuran Indikator Pembangunan Daerah di Era Otonomi dan Desentralisasi. Region, Vol. 2, No, 43-52.

Nugroho, R. (2006). Kebijakan Publik untuk Negara-negara Berkembang: Model-model Perumusan, Implementasi, dan Evaluasi. Jakarta: PT Elex Media Komputindo.

Perda Nomor 10 Tahun 1990 Tentang Pembinaan Pedagang Kaki Lima Kota Makassar. (n.d.).

Ray Bromley. (2000). Street Vending and Public Policy: A Global Review. International Journal of Sociology and Social Policy, Vol. 20 (Issue: 1/2), pp.1-28. 
https://doi.org/https://doi.org/10.1108/01443330010789052

Retno Widjajanti. (2014). Permasalahan lokasi pedagang kaki lima (pkl) dalam ruang perkotaan. tata loka, volume 16(2014 biro penerbit planologi undip).

Sumaryadi. (2005). Perencanaan Pembangunan Daerah Otonom dan Pemberdayaan Masyarakat. Jakarta: CV Citra Utama.

Wahab, A. (2005). Analisis Kebijaksanaan dari Formulasi ke Implementasi Kebijaksanaan Negara. Jakarta: Bumi Aksara.

Winarno, B. (2012). Kebijakan Publik: Teori, Proses dan Studi Kasus. Yogyakarta: CAPS. 